\title{
APLIKASI MODIFIED PROCTOR PADA ROLLER COMPACTED NO-FINES CONCRETE DENGAN AGREGAT 5-10 mm
}

\section{APPLICATION OF MODIFIED PROCTOR ON ROLLER COMPACTED NO-FINES CONCRETE USING5-10 mm AGGREGATE}

\author{
Abdias Tandy Arrang ${ }^{1)}$ \\ Staf Pengajar Pada Program Studi Teknik Sipil Universitas Kristen Indonesia Toraja
}

\begin{abstract}
The usage of no-fines concrete as pavement currently was being utilized. It was constituted by diversity effort of concrete cement pavement construction material, besides nofines concrete pavement having benefit that reduce water pond on pavement surface rapidly because of its pervious. Permeability character of no-fines concrete will recharge groundwater deposit therefore more environmental friendly. Problem faced is low strength of no-fines concrete as compared to conventional concrete. Therefore it is required the effort of increasing the strength of no-fines concrete by increase concrete density that is done by roller machine. No-fines concrete that is compacted by roller machine is called Roller Compacted No-fines Concrete (RCNC).

This research analyzed the increase of concrete properties especially compression strength and split tensile strength effected by external compaction using modified proctor in creating the laboratory specimen. Materials of no-fines concrete utilized Clereng coarse aggregate with size 5-10 mm, Gresik Portland cement and the aggregate cement ratio is 4 and 6. To accelerating the hardening concrete utilized admixture type $C$ which is sikaset accelerator with $20 \%$ of total water volume. The blow variation of modified Proctor per layer is 28, 42 and 56. Compression test and split tensile test been done at the age of 1 and 28 days.

Result of research showed the increase of concrete specific gravity and compression strength in line with the increase of blow variation. RCNC specific gravity acquired ranging between 1,544 and 1,788. Compression strength at the age of 28 days acquired were (1) aggregate cement ratio 4 with 28, 42, 56 blows per layer were 21,47 MPa, 22,92 MPa, 26,55 $\mathrm{MPa}$ (2) aggregate cement ratio 6 each were 8,48 MPa, 10,51 MPa, 14,82 MPa. Split tensile strength at the age of 28 days were (1) aggregate cement ratio 4 with 28, 42, 56 blows per layer each were 2,27 MPa, 2,92 MPa, 3,13 MPa (2) aggregate cement ratio 6 each were 1,63 $M P a, 1,83 M P a, 2,08 M P a$.
\end{abstract}

Key words: No-fines concrete, Roller compacted no-fines concrete (RCNC), Compression strength, Split tensile strength.

1) Mahasiswa Magister Sistem dan Teknik Transportasi Universitas Gadjah Mada, Yogyakarta

2) Dosen Teknik Sipil dan Magister Sistem dan Teknik Transportasi Universitas Gadjah Mada, Yogyakarta

PENDAHULUAN 


\section{Latar Belakang}

Usaha peningkatan kekuatan no-fines concretedilakukan dengan cara menambah kepadatan beton.Namun campuran no-fines concrete yang dibuat dalam faktor air semen rendah tidak dapat dipadatkan dengan denga vibratorseperti pada beton konvensional. Oleh karena itu pemadatan dilakukan dengan mengadopsi teknik roller compacted concrete (RCC) yaitu memadatkan beton di lapangan dengan menggunakan mesin gilas atau roller. Perkerasan no-fines concrete yang dipadatkan dengan mesin gilas ini disebut Roller Compacted No-fines Concrete $(R C N C)$.Penggunaan bahan tambah sikaset accelerator dimaksudkan untuk membantu pengikatan awal beton sehingga sifat campuran no-fines concrete yang mudah tercerai-berai dapat dihindari.

Pada penelitian ini digunakan alat modified Proctordalam pembuatan benda uji. Hal ini dimaksudkan untuk merancang suatu kepadatan beton yang diinginkan untuk perkerasan jalan.

\section{Tujuan Penelitian}

Tujuan penelitian adalah untuk mengetahui pengaruh variasi jumlah tumbukan $(5 \times 28$, $5 \times 42$, dan 5x56), variasi rasio agregat semen $(4: 1 ; 6: 1)$, dan umur beton (1 dan 28 hari) $R C N C$ yang menggunakan sikaset accelerator terhadap :

1. Kepadatan beton

2. Kuat tekan beton.

3. Kuat tarik belah beton.

\section{TINJAUAN PUSTAKA}

\section{No-fines Concrete}

No-fines concrete atau beton tanpa pasir adalah beton yang diperoleh dengan cara menghilangkan bagian halus agregat pada pembuatan beton. Tidak adanya agregat halus dalam campuran menghasilkan suatu sistem berupa keseragaman rongga yang terisitribusi di dalam massa beton, serta berkurangnya berat jenis beton. Rongga di dalam beton tersebut mencapai sekitar 20 sampai 25 persen (Tjokrodimulyo, 2007).

\section{Sifat beton segar}

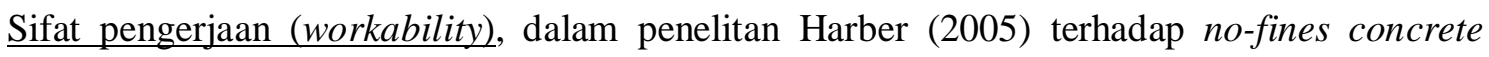
gradasi 4,75-20 mm dan rasio agregat semen 4,5 diperoleh slump $16 \mathrm{~cm}$ dan VB time 3 detik.

Pemisahan agregat kasar (segregation), No-fines concrete tidak mudah mengalami segregation meskipun dituang dari tempat yang cukup tinggi (Raju, 1983).

\section{Sifat Beton Keras}


Kepadatan, berat beton no-fines concrete dipengaruhi oleh berat jenis agregat, berat satuan agregat dan proporsi agregat dengan semen. Berat satuan beton yang pernah dicapai dalam beberapa penelitian dapat dilihat pada Tabel 2.1.

Tabel. 2.1. Berat satuan no-fines concrete

\begin{tabular}{|c|c|c|c|}
\hline \multirow{2}{*}{$\begin{array}{c}\text { Rasio } \\
\text { Agregat }\end{array}$} & \multicolumn{3}{|c|}{ Berat Satuan No-Fines Concrete $\left(\mathrm{ton} / \mathrm{m}^{3}\right)$} \\
\cline { 2 - 4 } & Kerikil Galis & Batu Kapur Klaten & Kerikil Mahakam \\
\cline { 2 - 4 } & $5-10 \mathrm{~mm}$ & $5-10 \mathrm{~mm}$ & $5-10 \mathrm{~mm}$ \\
\hline 2 & 2,19 & 2,12 & 2,38 \\
\hline 4 & 2,07 & 2,06 & 2,19 \\
\hline 6 & 1,89 & 1,85 & 2,03 \\
\hline 8 & 1,82 & 1,83 & 1,92 \\
\hline 10 & 1,77 & 1,74 & 1,90 \\
\hline $\begin{array}{c}\text { Peneliti } \\
\text { tahun) }\end{array}$ & Kadarusman(1998) & $\begin{array}{c}\text { Nugroho } \\
(2003)\end{array}$ & $\begin{array}{c}\text { Pradono } \\
(2008)\end{array}$ \\
\hline
\end{tabular}

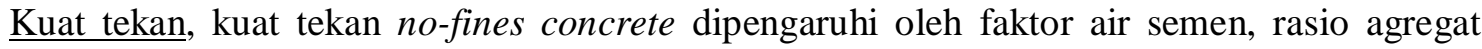
semen dan jenis agregatnya (Tjokrodimuljo, 2007). Kuat tekan no-fines concrete lebih rendah jika dibandingkan dengan beton konvensional. Kuat tekan yang dicapai oleh no-fines concrete dari beberapa penelitian dapat dilihat pada Tabel 2.2.

Tabel 2.2. Kuat tekan no-fines concrete

\begin{tabular}{|c|c|c|c|c|}
\hline \multirow{2}{*}{$\begin{array}{c}\text { Rasio } \\
\text { Agregat } \\
\text { Semen }\end{array}$} & \multicolumn{4}{|c|}{ Kuat Tekan No-Fines Concrete (MPa) } \\
\cline { 2 - 5 } & Kerikil Galis & $\begin{array}{c}\text { Batu } \\
\text { KapurKlaten }\end{array}$ & Queensland & $\begin{array}{c}\text { Kerikil } \\
\text { Mahakam }\end{array}$ \\
\cline { 2 - 5 } & $5-10 \mathrm{~mm}$ & $5-10 \mathrm{~mm}$ & $4,75-20 \mathrm{~mm}$ & $5-10 \mathrm{~mm}$ \\
\hline 2 & 35,87 & 36,98 & - & 32,34 \\
\hline 4 & 16,41 & 17,93 & - & 24,37 \\
\hline 4,5 & - & - & 18,2 & - \\
\hline 6 & 10,37 & 11,67 & - & 12,79 \\
\hline 8 & 6,86 & 9,47 & - & 8,67 \\
\hline 10 & 4,61 & 2,76 & - & 7,03 \\
\hline $\begin{array}{c}\text { Peneliti } \\
\text { (tahun) }\end{array}$ & $\begin{array}{c}\text { Kadarusman } \\
(1998)\end{array}$ & $\begin{array}{c}\text { Nugroho } \\
(2003)\end{array}$ & $\begin{array}{c}\text { Harber } \\
(2005)\end{array}$ & $\begin{array}{c}\text { Pradono } \\
(2008)\end{array}$ \\
\hline
\end{tabular}

\section{Pemadatan}

Perkerasan beton semen yang menggunakan teknik roller compacted concrete $(R C C)$ dipadatkan dengan menggunkan roller atau alat penggilas sehingga diperoleh kepadatan yang diinginkan.

\section{LANDASAN TEORI}

\section{Bahan Tambah}

Bahan tambahan atau admixture adalah suatu produksi disamping bahan semen, agregat dan air, yang juga dicampurkan dalam spesi beton. Tujuan dari penambahan bahan tambah ini adalah untuk memperbaiki sifat-sifat tertentu dari campuran beton lunak dan keras. Secara 
umum bahan tambah yang digunakan dalam beton dapat dibedakan menjadi dua yaitu bahan tambah yang bersifat kimiawi (chemical admixture) dan bahan tambah yang bersifat mineral (additive) (Mulyono, 2005).

\section{Kepadatan (Berat per $\mathbf{m}^{3}$ )}

Berat per $\mathrm{m}^{3}$ no-fines concrete dipengaruhi oleh berat jenis agregat, berat satuan agregat, rasio agregat semen dan usaha pemadatan yang dilakukan terhadap beton. Berat jenis dan berat satuan yang tinggi akan menghasilkan berat beton yang tinggi. Semakin tinggi rasio agregat semen akan menghasilkan berat beton yang semakin rendah. Berat per $\mathrm{m}^{3}$ beton dinyatakan dalam $\mathrm{kg} / \mathrm{m}^{3}$.

\section{Kuat Tekan (compression strength)}

Kuat tekan adalah besarnya beban per satuan luas yang menyebabkan benda uji hancur bila dibebani dengan gaya tekan tertentu yang dihasilkan dari mesin uji tekan.

Kuat tekan beton dapat ditentukan dengan rumus berikut (SNI 03-1974-1990) :

$$
\text { fc' } \quad=\frac{P}{A}
$$

dengan:

$f_{c} \quad=$ kuat tekan beton $(\mathrm{MPa})$

$P \quad=$ beban maksimum $(\mathrm{N})$

$A \quad=$ luas penampang benda uji $\left(\mathrm{mm}^{2}\right)$

Bentuk silinder standar untuk uji kuat tekan adalah tinggi (h) dua kali dari diameter (d) benda uji. Namun karena keterbatasan, seringkali bentuk standar tersebut tidak dapat dipenuhi. Akibatnya kuat tekan yang didapatkan adalah relative strength, semakin besar rasio h/d semakin kurang kuat tekan yang didapatkan. Oleh karena itu dibutuhkan koreksi terhadap kuat tekan hasil pengujian untuk mendapatkan kuat tekan yang sebenarnya. Nevill (1975) memberikan hubungan antara rasio perbandingan h dan d seperti pada Gambar 3.1.

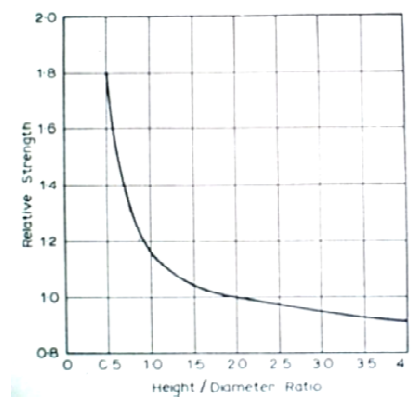

Gambar 3.1. Grafik pola hubungan antara rasio h/d terhadap apparent strength benda uji silinder

Kuat tekan beton bertambah tinggi dengan bertambahnya umur. Rasio kuat tekan beton pada berbagai umur menurut SNI T-15-1991-03dapat dilihat pada Tabel 3.1. 
Tabel 3.1. Rasio kuat tekan beton pada berbagai umur

\begin{tabular}{|l|c|c|c|c|c|c|c|}
\hline Umur Beton (Hari) & 3 & 7 & 14 & 21 & 28 & 90 & 365 \\
\hline Semen Portland biasa & 0,40 & 0,65 & 0,88 & 0,95 & 1,00 & 1,20 & 1,35 \\
\hline $\begin{array}{l}\text { Semen Portland dengan kekuatan } \\
\text { awal yang tinggi }\end{array}$ & 0,55 & 0,75 & 0,90 & 0,95 & 1,00 & 1,15 & 1,20 \\
\hline
\end{tabular}

\section{Kuat tarik belah (splittensile strength)}

Uji kuat tarik dilakukan dengan dengan memberikan tegangan tarik pada beton secara tidak langsung. Pada pengujian ini silinder beton dengan tipe yang sama dengan yang dipergunakan pada pengujian kuat tekan diletakkan secara horisontal di antara pelat alat uji. Kemudian dibebani sampai terbelah secara vertikal sepanjang diameter benda uji (Nevill, 1975).

Hitungan kuat tarik belah dari benda uji dengan menggunakan rumus sebagai berikut (Yoder dan Witzcak, 1975):

$$
\text { fct } \quad=\frac{2 P}{\pi L D}
$$

dengan :

$$
\begin{aligned}
f c t & =\text { kuat tarik belah }(\mathrm{MPa}) \\
P & =\text { beban maksimum pada mesin (benda belah/hancur) }(\mathrm{N}) \\
L & =\text { panjang benda uji }(\mathrm{mm}) \\
D & =\text { diameter benda uji }(\mathrm{mm})
\end{aligned}
$$

\section{Kuat tarik lentur (flexural Strength)}

Pedoman xx-2002 Departemen Kimpraswil mensyaratkan kekuatan yang dipergunakan dalam perencanaan perkerasan jalan beton semen adalah nilai kuat tarik lentur (flexural strength) umur 28 hari yang besarnya secara tipikal sekitar 3-5 MPa.

Hubungan antara kuat tekan dengan kuat tarik lentur beton dapat didekati dengan rumus (Departemen Kimpraswil, 2002):

$$
\mathrm{f}_{\mathrm{cf}} \quad=K \sqrt{f c^{\prime}} \text { dalam MPa }
$$

dengan:

$\mathrm{f}_{\mathrm{cf}} \quad=$ Kuat tarik lentur umur 28 hari $(\mathrm{MPa})$

fc' $\quad=$ Kuat tekan umur 28 hari $(\mathrm{MPa})$

$\mathrm{K}=$ Konstanta 0,7 untuk agregat tidak pecah dan 0,75 untuk agregat pecah

Kuat tarik lentur juga dapat ditentukan dari hasil uji kuat tarik belah beton yang dilakukan menurut SNI-2491-1991 sebagai berikut (Departemen Permukiman dan Prasarana Wilayah, 2002): 
$\mathrm{f}_{\mathrm{cf}} \quad=1,37 f c t$ dalam MPa

dengan:

$\mathrm{f}_{\mathrm{ct}} \quad=$ Kuat tarik belah umur 28 hari $(\mathrm{MPa})$

Persamaan (3.4) dan persamaan (3.5) memperlihatkan hubungan antara kuat tekan $\left(f c^{\prime}\right)$ dengan kuat tarik belah $(f c t)$ beton pada umur 28 hari, sebagai berikut (digunakan agregat pecah) :

$$
\begin{aligned}
& 1,37 f c t=0,75 \sqrt{f c^{\prime}} \\
& f c t \quad=0,55 \sqrt{f c^{\prime}}
\end{aligned}
$$

Nilai 0,55 adalah konstanta yang disebut $\alpha$.

\section{Roller Compacted No-fines Concrete (RCNC)}

Untuk meningkatkan kekuatan no-fines concrete maka dibutuhkan alat pemadat eksternal. Seperti yang dilakukan pada roller compacted concrete (RCC), agar bidang gesek antar agregat semakin besar maka campuran no-fines concrete dipadatkan dengan rollersehingga diperoleh kekuatan yang lebih besar dibandingkan dengan no-fines concrete konvensional. No-fines concrete yang dipadatkan dengan roller ini disebut Roller Compacted No-Fines Concrete (RCNC).

\section{ModifiedProctordan Standard Proctor}

Alat Proctor test berupa pemadatan dengan cara menumbuk. Sebuah alat penumbuk dijatuhkan beberapa kali di atas tanah yang berada dalam mould. Dengan berkembangnya alat-alat penggilas berat yang digunakan pada pemadatan dilapangan, Proctor test standar dimodifikasi untuk dapat lebih mewakili kondisi lapangan. Uji Proctor yang dimodifikasi ini disebut modified Proctor test(Das, 1998). Tabel 3.2. menampilkan perbandingan antara standardProctor denganmodified Proctor.

Tabel. 3.2. Perbandingan antara standard Proctor dengan modified Proctor

\begin{tabular}{|c|c|c|}
\hline Spesifikasi & Standard Proctor & Modified Proctor \\
\hline Tinggi jatuh & $30 \mathrm{~cm}(12$ ") & $45,7 \mathrm{~cm}\left(18^{\prime \prime}\right)$ \\
\hline Berat penumbuk & $2,5 \mathrm{~kg}(5,5 \mathrm{lb})$ & $4,54 \mathrm{~kg}(10 \mathrm{lb})$ \\
\hline Tumbukan per lapis & 25 tumbukan & 25 tumbukan \\
\hline Jumlah lapis & 3 lapis & 5 lapis \\
\hline Tinggi Mould & $116,43 \mathrm{~mm}$ & $116,43 \mathrm{~mm}$ \\
\hline Diameter Mould & $152,4 \mathrm{~mm}$ & $152,4 \mathrm{~mm}$ \\
\hline
\end{tabular}

\section{METODOLOGI PENELITIAN}

\section{Bahan Penelitian}


Bahan-bahan yang dibutuhkan pada penelitian ini adalah agregat kasar asal Clerengukuran 5-10 mm, semen Portland produksi PT. Semen Gresik dan air.Bahan Tambah yang digunakan berupa chemical admixture tipe C"accelerating admixtures" produksiPT. Sika Indonesia dengan merk dagang Sikaset Accelerator.

\section{Peralatan pengujian}

Peralatan pengujian beton segaryaitu VB test,stopwatch,kerucut Abrams dan pita ukur. Peralatan pengujian beton keras yaitu alat uji kuat tekan kapasitas $2000 \mathrm{kN}$ dengan ketelitian $1 \mathrm{kN}$ untuk uji kuat tarik belah, alat uji yang digunakan sama dengan alat uji kuat tekan namun karena nilai kuat tarik belah relatif rendah terhadap nilai kuat tekan, maka digunakan alat bantu untuk membaca nilai kuat tarik belah yaitu load cell dan strain meter dengan ketelitian $0,1 \mathrm{kN}$.

\section{Tahap Penentuan Benda Uji}

Penelitian ini menggunakan 72 benda uji, yang dibagi menjadi 36 benda uji untuk pengujian kuat tekan beton dan 36 benda uji untuk pengujian kuat tarik belah beton. Tiga puluh enam benda uji kuat tekan tersebut dibagi masing-masing 18 benda uji dengan rasio agregat semen 4 dan 6, dan tiap variasi tumbukan diwakili oleh 3 benda uji. Demikian pula untuk benda uji kuat tarik belah.

\section{Tahap perancangan campuran (mix design)no-fines concrete}

Perancangan campuran no-fines concretedilakukan berdasarkan perbandingan volume antara agregat dengan semen yaitu 4 dan6 dengan faktor air semen (f.a.s.) sebesar 0,35.

\section{HASIL PENGUJIAN DAN PEMBAHASAN}

\section{Agregat kasar}

Sifat-sifat agregat kasar asal Clereng diperoleh dari data sekunder yang didapatkan dari Laboratorium Transportasi, Jurusan Teknik Sipil dan Lingkungan, Universitas Gadjah Mada terlihat pada Tabel 5.1.

Tabel 5.1. Sifat-sifat agregat kasar asal Clereng

\begin{tabular}{|l|c|}
\hline \multicolumn{1}{|c|}{ Keterangan } & Nilai \\
\hline Berat jenis kering (bulk) & 2,562 \\
\hline Berat jenis permukaan jenuh $(S S D)$ & 2,609 \\
\hline Berat jenis semu (apparent) & 2,688 \\
\hline Penyerapan (absorbtion) $(\%)$ & 1,836 \\
\hline Keausan dengan mesin abrasi Los Angeles $(\%)$ & 23,5 \\
\hline
\end{tabular}

Berat satuan agregat 5-10 $\mathrm{mm}$ Clereng adalah $1,39 \mathrm{ton} / \mathrm{m}^{3}$.

\section{Bahan Tambah}


Sikaset Accelerator termasuk bahan tambah jenis C "accelerating admixture" yang berfungsi untuk mempercepat pengerasan beton. Bahan tambah diperoleh dalam kemasan yang masih tertutup rapat. Sikaset Acceleratorberbentuk cairan dan berwarna agak keruh.

\section{Perhitungan kebutuhan bahan}

Hasil perhitungan kebutuhan bahan pembuatan $1 \mathrm{~m}^{3}$ beton untuk tiap variasi rancangan campuran dapat dilihat pada Tabel 5.2.

Tabel 5.2. Perincian kebutuhan bahan dasar untuk pembuatan benda uji per $\mathrm{m}^{3}$

\begin{tabular}{|c|c|c|c|c|c|c|c|c|c|}
\hline \multirow{4}{*}{ 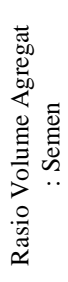 } & \multicolumn{3}{|c|}{ Agregat Kasar } & \multicolumn{3}{|c|}{ Semen } & \multicolumn{3}{|c|}{ Air } \\
\hline & \multirow{2}{*}{$\begin{array}{l}\stackrel{0}{\Xi} \\
\stackrel{\Xi}{0}\end{array}$} & \multirow{2}{*}{ 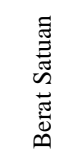 } & \multirow{2}{*}{$\begin{array}{l}\bar{\pi} \\
\stackrel{\pi}{0} \\
\infty\end{array}$} & \multirow{2}{*}{$\frac{\mathscr{g}}{3}$} & \multirow{2}{*}{ 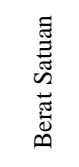 } & \multirow{2}{*}{ 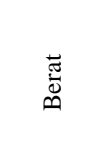 } & \multirow{2}{*}{ 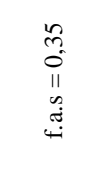 } & \multicolumn{2}{|c|}{$\begin{array}{l}\text { sikaset accelerator } \\
20 \% \text { dari total air }\end{array}$} \\
\hline & & & & & & & & $\begin{array}{c}\text { Sikaset } \\
\text { Acc. }\end{array}$ & Air \\
\hline & $\mathrm{m}^{3}$ & $\mathrm{~kg} / \mathrm{m}^{3}$ & $\mathrm{~kg}$ & $\mathrm{~m}^{3}$ & $\mathrm{~kg} / \mathrm{m}^{3}$ & $\mathrm{~kg}$ & liter & liter & liter \\
\hline 4 & & & & 0,29 & & 359,38 & 125,78 & 25,16 & 100,63 \\
\hline 6 & 1,15 & 1390 & 1598,5 & 0,19 & 1250 & 239,58 & 83,85 & 16,77 & 67,08 \\
\hline
\end{tabular}

\section{Pengujian workability}

Uji workability dilakukan dengan alat $V B$ test.Hasil dari uji tersebut diperlihatkan pada Tabel 5.3.

Tabel 5.3. Hasil Uji Workabilitas dengan Alat VB test

\begin{tabular}{|c|c|c|}
\hline Rasio Agregat : Semen & $\begin{array}{c}\text { Vebe Test } \\
(\text { detik })\end{array}$ & $\begin{array}{c}\text { Slump } \\
(\mathrm{cm})\end{array}$ \\
\hline 4 & 13 & 14 \\
\hline 6 & 16 & 12 \\
\hline
\end{tabular}

Semakin tinggi nilai rasio agregat semen campuran semakin keras sehingga semakin susah untuk dikerjakan.

\section{Berat per $\mathbf{m}^{3}$}

Kecenderungan menunjukkan bahwa semakin kecil nilai rasio agregat semen kepadatan semakin meningkat, sedangkan semakin tinggi jumlah tumbukan kepadatan semakin besar. Kepadatan beton hasil penelitian berkisar antara $1544-1788 \mathrm{~kg} / \mathrm{m}^{3}$

Perbandingan $R C N C$ Clereng dengan berbagai variasi tumbukan terhadap berat beton nofines concrete dengan ukuran agregat yang sama dari beberapa penelitian dapat dilihat ilustrasinya pada Gambar 5.1. 


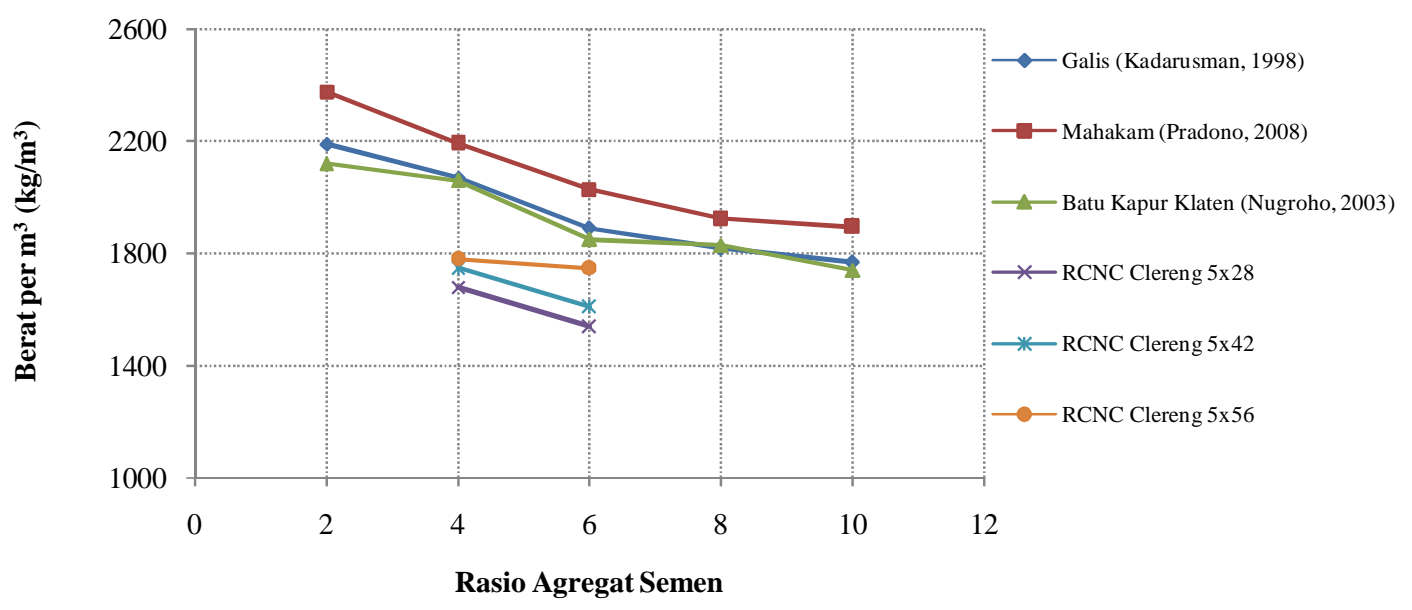

Gambar 5.1. Grafik perbandingan berat beton per $\mathrm{m}^{3} R C N C$ dari agregat Clereng dengan no-fines concrete penelitian lain (agregat $5-10 \mathrm{~mm}$ )

\section{Kuat tekan}

Hasil penelitian memperlihatkan bahwa kuat tekan $R C N C$ dipengaruhi oleh rasio agregat semen dan jumlah tumbukan (pemadatan). Pada rasio agregat semen yang tinggi kuat tekan yang diperoleh rendah, sementara pada jumlah tumbukan yang semakin tinggi cenderung diperoleh kuat tekan yang semakin tinggi. Kuat tekan tertinggi dalam penelitian ini dicapai pada rasio agregat 4 dan jumlah tumbukan 56 tiap lapis, yaitu sebesar 26,55 MPa. Sementara kuat tekan terendah sebesar 6,08 MPa diperoleh pada rasio agregat semen 6 dengan jumlah tumbukan 28 per lapis.

Kuat tekan $R C N C$ agregat 5-10 $\mathrm{mm}$ asal Clereng jika dibandingkan dengan no-fines concrete dari beberapa penelitian terdahulu pada gradasi agregat yang sama dapat dilihat ilustrasinya pada Gambar 5.2. 


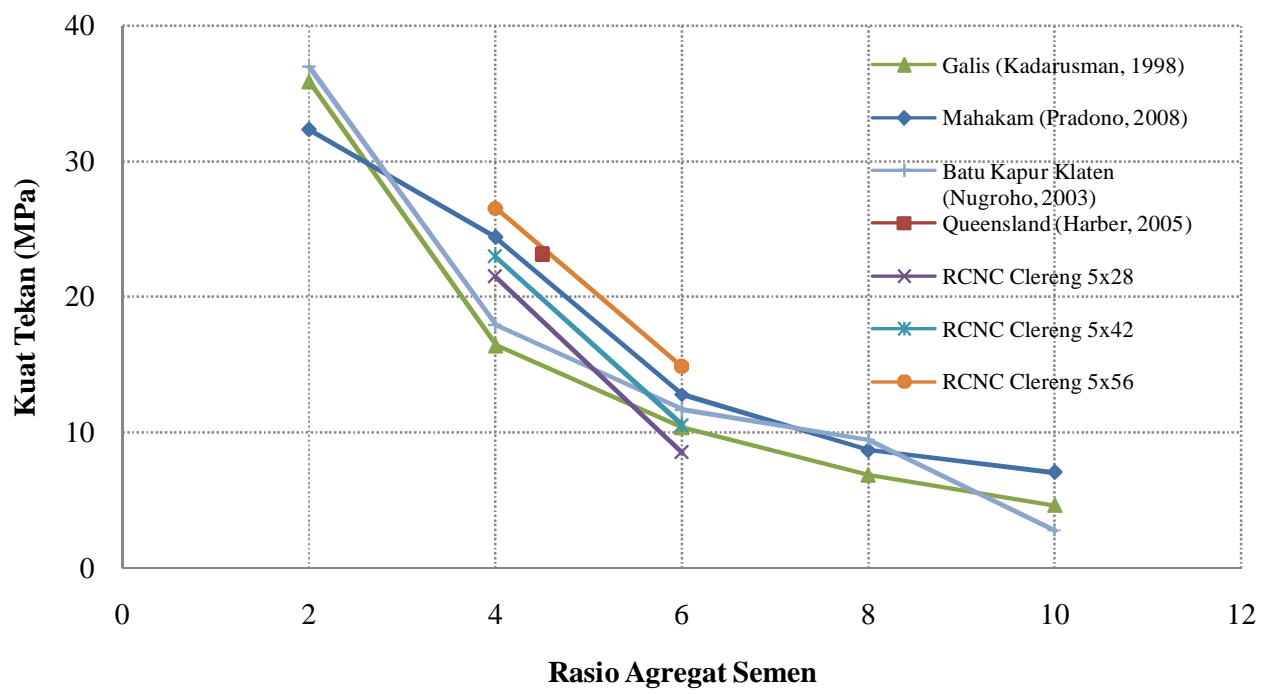

Gambar 5.2. Grafik perbandingan kuat tekan beton $R C N C$ agregat $5-10 \mathrm{~mm}$ asal Clereng dengan rasio agregat semen 4 dan 6 dengan no-fines concrete penelitian terdahulu dengan gradasi yang sama

Perbandingan rasio kuat tekan $R C N C$ yang diperoleh dalam penelitian dengan rasio kuat tekan SNI T-15-1991-03 diperlihatkan pada Gambar 5.3.

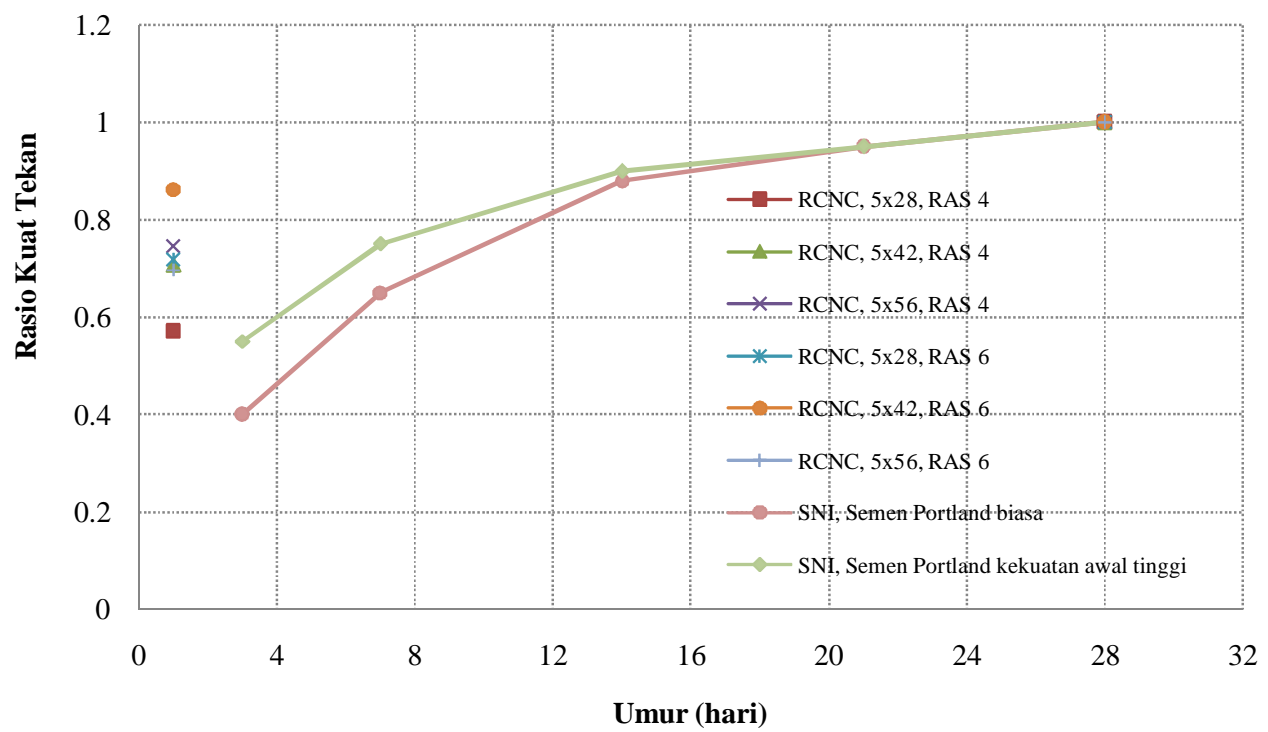

Gambar 5.3. Grafik perbandingan rasio kuat tekan $R C N C$ hasil penelitian dengan rasio kuat tekan SNI T-15-1991-03

Jika dibandingkan dengan rasio kuat tekan yang diberikan oleh SNI T-15-1991-03 seperti yang dituliskan pada Tabel 3.1., terlihat bahwa rasio kuat tekan $R C N C$ agregat 5-10 $\mathrm{mm}$ asal Clereng yang diperoleh dari hasil pengujian cukup tinggi. Rasio kuat tekan terendah umur 1 hari pada beton rasio agregat semen 4 dengan tumbukan 28 per lapis sebesar 0,57, sementara yang tertinggi terdapat pada beton rasio agregat semen 6 dengan tumbukan 42 per 
lapis yaitu sebesar 0,86. Sedangkan rasio kuat tekan dari SNI T-15-1991-03 pada umur 3 hari adalah 0,4 untuk beton dengan semen portland biasa dan 0,55 untuk semen portland dengan kekuatan awal yang tinggi. Tingginya rasio kuat tekan pada umur 1 hari tersebut disebabkan oleh karena penggunaan bahan tambah tipe $\mathrm{C}$ sikaset accelerator pada pembuatan benda uji.

\section{Kuat tarik belah}

Pada rasio agregat semen 4, peningkatan jumlah tumbukan dari 28 per lapis ke 42 per lapis meningkatkan kuat tarik belah sebesar 0,65 MPa (28,63\%); sementara peningkatan jumlah tumbukan dari 42 per lapis ke 56 tumbukan per lapis terjadi peningkatan sebesar 0,21 $\operatorname{MPa}(7,19 \%)$.

Untuk benda uji dengan rasio agregat semen 6, peningkatan jumlah tumbukan dari 28 menjadi 42 per lapis meningkatkan kuat tarik belah sebesar 0,2 MPa (12,27\%); dan pada peningkatan tumbukan dari 42 ke 56 per lapis terjadi peningkatan sebesar 0,25 $\mathrm{MPa}$ $(13,66 \%)$.

Kuat tarik belahRCNC agregat 5-10 $\mathrm{mm}$ asal Clereng jika dibandingkan dengan no-fines concrete dari penelitian terdahulu dapat dilihat ilustrasinya pada Gambar 5.4.

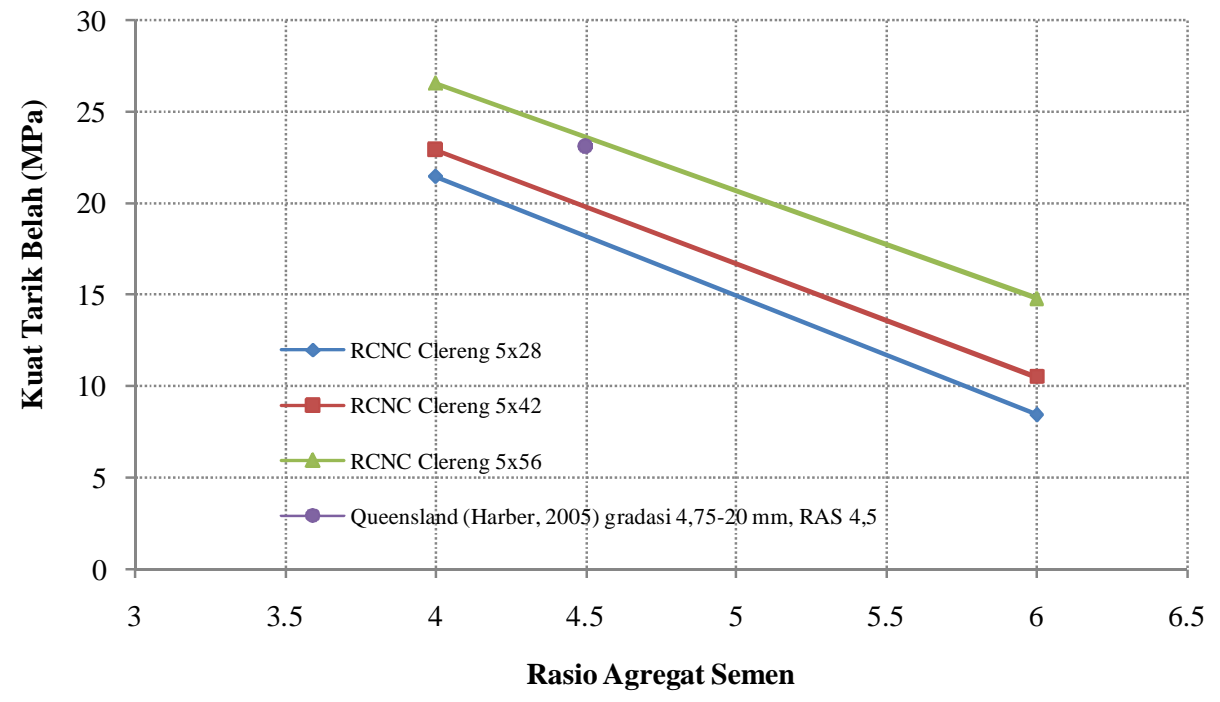

Gambar 5.4. Grafik perbandingan kuat tarik belahbeton $R C N C$ agregat $5-10 \mathrm{~mm}$ asal Clereng rasio agregat semen 4 dan 6 dengan no-fines concrete penelitian terdahulu

Rasio kuat tarik belah $R C N C$ agregat 5-10 $\mathrm{mm}$ asal Clereng yang ditambahkan dengan sikaset accelerator(20\% dari jumlah total air) pada umur 1 hari berkisar dari 0,55 sampai dengan 0,79. Hal ini memperlihatkan bahwa kuat tarik belah pada umur 1 hari telah mencapai $55-79 \%$ dari kuat tarik belah pada umur 28 hari (umur rencana). 


\section{Perbandingan kuat tekan dan kuat tarik belah}

Perbandingan kuat tekan beton ( $\left.f c^{\prime}\right)$ dengan kuat tarik belah $(f c t) R C N C$ agregat 5-10 mm asal Clereng pada umur 28 hari diperlihatkan pada Gambar 5.5.

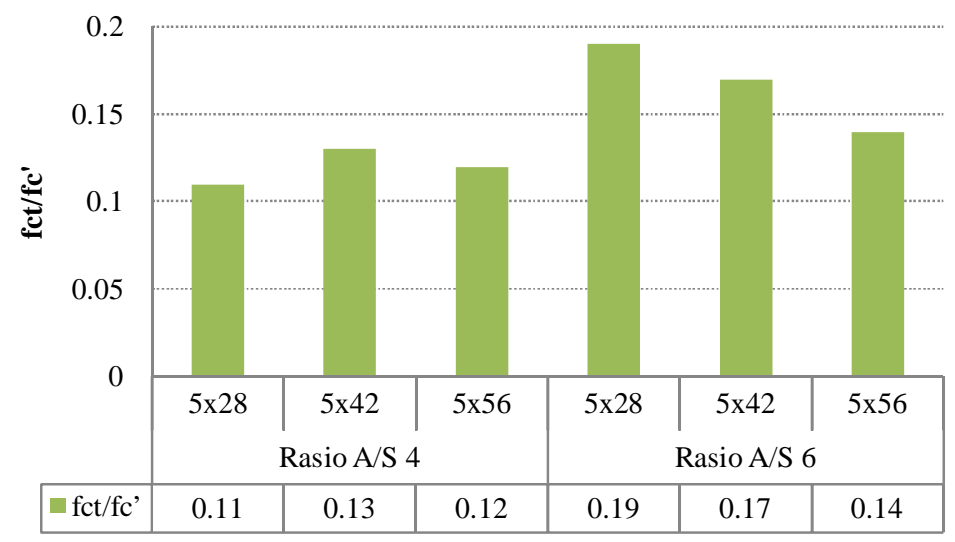

Gambar 5.5. Grafik nilai $f c t / f c^{\prime} R C N C$ agregat $5-10 \mathrm{~mm}$ asal Clereng dengan rasio agregat semen 4 dan 6 pada umur beton 28 hari

Pada awal umur beton (umur 1 hari), nilai $f c t / f c^{\prime}$ yang didapatkan untuk 2 jenis rasio agregat semen yang diteiliti berkisar antara 10-15\%; sedangkan pada umur 28 hari berkisar antara $10-19 \%$. Sebagai perbandingan, untuk beton normal kuat tarik belah terhadap kuat tekan pada umur 28 hari berkisar antara 9-15\%.

Nilai $\alpha R C N C$ yang diperoleh dalam penelitian ini pada umur 28 hari diperlihatkan pada Gambar 5.6.

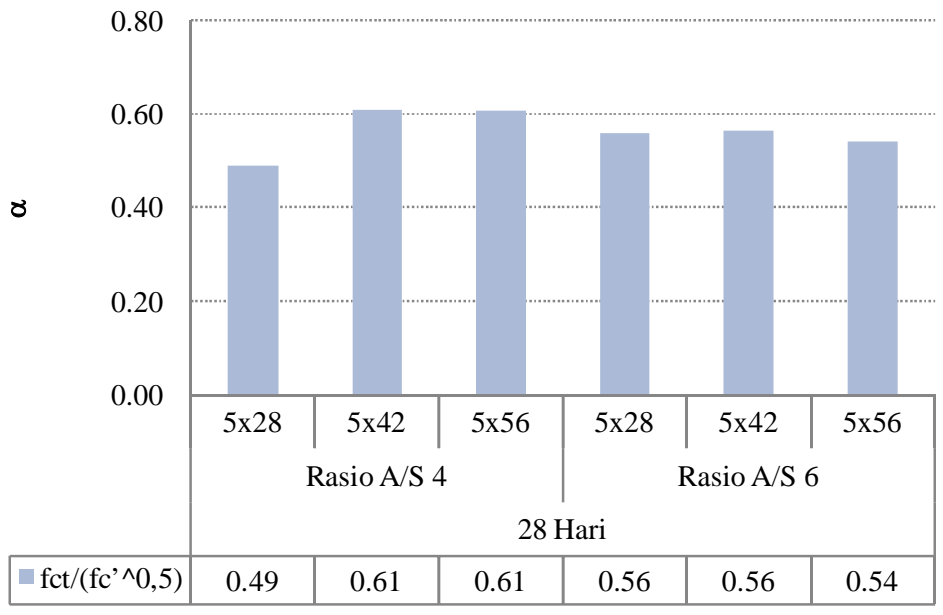

Gambar 5.6. Grafik nilai $\alpha R C N C$ agregat $5-10 \mathrm{~mm}$ asal Clereng dengan rasio agregat semen 4 dan 6 pada umur beton 28 hari

Nilai $\alpha R C N C$ Clereng hasil penelitain dengan rasio agregat semen 4 dan 6 pada umur 28 hari berkisar antara 0,49 sampai 0,61 . 


\section{Kuat tarik lentur}

Dengan menggunakan persamaan (3.5) pada Bab III maka diperoleh kuat tarik lentur pada umur 28 hari seperti pada Gambar 5.7.



Gambar 5.7. Grafik Nilai Kuat lentur $R C N C$ Clereng agregat $5-10 \mathrm{~mm}$

Dari Gambar 5.7. dapat dilihat bahwa kuat tarik lentur RCNC Clereng 5-10 mm hasil penelitian berkisar pada 2,24 - 4,29 MPa. Berdasarkan ketentuan pada Pedoman xx-2002 Departemen Permukiman dan Prasarana Wilayah bahwa nilai kuat tarik lentur pada umur 28 hari untuk struktur jalan beton semen besarnya adalah 3 - $5 \mathrm{MPa}$ maka dapat disimpulkan bahwa kuat tarik lentur $R C N C$ Clereng dengan rasio agregat 4 memenuhi syarat untuk menjadi bahan struktur jalan beton semen. Sementara $R C N C$ Clereng dengan rasio agregat semen 6 yang kuat tarik lenturnya lebih kecil dari $3 \mathrm{MPa}$ dapat dimanfaatkan sebagai lapisan pondasi perkerasan.

\section{KESIMPULAN DAN SARAN}

\section{Kesimpulan}

Kesimpulan terhadap penelitianRoller Compacted No-fines Concrete agregat 5-10 mm asal Clereng dengan bahan tambah sikaset accelerator (20\% berat total air) dan faktor air semen 0,35 yang dipadatkan dengan modified Proctor adalah:

1. Kepadatan beton, semakin rendah rasio agregat semen berat per $m^{3}$ beton cenderung semakin tinggi; semakin tinggi jumlah tumbukan (pemadatan) tiap lapis berat jenis beton cenderung semakin tinggi. Kepadatan beton hasil penelitian berkisar antara $1544-1788$ $\mathrm{kg} / \mathrm{m}^{3}$. 
2. Kuat tekan beton, semakin rendah rasio agregat semen kuat tekan cenderung semakin tinggi; semakin tinggi jumlah tumbukan (pemadatan) tiap lapis kuat tekan beton cenderung semakin tinggi. Kuat tekan hasil penelitian berkisar antara 8,48 - 26,55 MPa. Rasio kuat tekan umur 1 hari cukup tinggi yaitu 0,57-0,86.

3. Kuat tarik belah beton, semakin rendah rasio agregat semen kuat tarik belah cenderung semakin tinggi; semakin tinggi jumlah tumbukan (pemadatan) tiap lapis kuat tekan beton cenderung semakin tinggi. Kuat Tarik belah hasil penelitian berkisar antara 1,63 - 3,13 MPa. Rasio kuat tarik belah terhadap kuat tekan pada umur 28 hari sebesar 0,11 - 0,19. Sementara nilai $\alpha$ sebesar $0,49-0,61$.

\section{Saran}

Untuk melengkapi penelitian ini, masih diperlukan beberapa penelitian lanjut antara lain:

1. Penelitian rongga udara, pencarían nilai faktor air semen optimum pada $R C N C$ agregat 5$10 \mathrm{~mm}$ asal Clereng, variasi berat bahan tambah sikaset accelerator terhadap berat air total.

2. Untuk mendapatkan nilai rasio kuat tekan yang lebih lengkap diperlukan pengamatan pada umur 3, 7, 14, 21 dan 90 hari.

3. Penelitian terhadap keawetan $R C N C$ sebagai perkerasan.

4. Perlu penelitian menggunakan agregat dengan berat satuan yang lebih besar dari yang digunakan dalam peneltian ini, misalnya agregat dengan berat satuan antara $1500-1600$ $\mathrm{kg} / \mathrm{m}^{3}$.

\section{DAFTAR PUSTAKA}

Das, Braja M., 2000, "Fundamentals of Geotechnical Engineering", Brooks/Cole, California.

Departemen Kimpraswil RI, 2002, "Pedoman Perencanaan Jalan Beton Semen". Departemen Pemukiman dan Prasarana Wilayah, Jakarta.

Departemen Kimpraswil RI, 2002, "Pedoman Tata Cara Pelaksanaan Beton Padat Giling $(B P G)$ ”. Departemen Pemukiman dan Prasarana Wilayah, Jakarta.

Dipohusodo, I., 1994, "Struktur Beton Bertulang:Berdasarkan SK SNI T-15-1991-03, Departemen Pekerjaan Umum", Gramedia Pustaka Umum, Jakarta.

Harber, P. J., 2005, ”Applicability of No-Fines Concrete as a Road Pavement”, Dissertation, University of Southern Queensland, Queensland.

Kadarusman, 1996, "Kajian Pemakaian Kerikil Galis sebagai Agregat pada Beton Non Pasir", Tugas Akhir, Jurusan teknik Sipil dan Lingkungan, Universitas Gadjah Mada, Yogyakarta.

Mulyono, T., 2005, ”Teknologi Beton", Penerbit Andi, Yogyakarta. 
Murdock, L.J., and Brook, K.M., dan Hendarko, S., 1986, "Bahan dan Praktek Beton Edisi Keempat", Penerbit Erlangga, Jakarta.

Neville, A. M., 1975, "Properties of Concrete", ELBS and Pitman Publishing, London.

Neville, A. M., and Brooks, J.J., 1987, "Concrete Technology", Longman Scientific \& Technical, New York.

Nugraha, P. dan Antoni, 2007, "Teknologi Beton dari Material, Pembuatan, ke Beton Kinerja Tinggi", Penerbit Andi, Yogyakarta.

Nugroho, A. S. B.,2003, "Beton Non Pasir dengan Agregat Batu kapur asal Klaten Ukuran $5 \mathrm{~mm}-10 \mathrm{~mm}$ ", Tugas Akhir, Jurusan teknik Sipil dan Lingkungan, Universitas Gadjah Mada, Yogyakarta.

Pradono, E., 2008, ”Penggunaan Kerikil Mahakam untuk Beton Non Pasir”, tesis, Program Pascasarjana Universitas Gadjah Mada, Yogyakarta.

Priyosulistyo, Hrc., 2002, "Bahan Konstruksi Lapis Keras Bagian Kedua : Rigid Pavement", Bahan Kuliah Magister Sistem dan Teknik Universitas Gadjah Mada, Yogyakarta.

Raju, N. K., 1983, "Design of Concrete Mixes", CBS Publishers \& Distributors, Delhi.

SNI 03-1974-1990, 1990, " Metode Pengujian Kuat Tekan Beton”.Pusat Penelitian dan Pengembangan Prasarana Transportasi, Balitbang Departemen Kimpraswil, Bandung.

SNI 03-2491-2002, 2002, " Metode Pengujian Kuat Tarik Belah Beton”.Pusat Penelitian dan Pengembangan Prasarana Transportasi, Balitbang Departemen Kimpraswil, Bandung.

Subkhannur, A.,2002, "Penggunaan Kerikil Asal Gunung Merapi sebagai Agregat dalam pembuatan beton Non Pasir", Tugas Akhir, Jurusan teknik Sipil dan Lingkungan, Universitas Gadjah Mada, Yogyakarta.

Tjokrodimuljo, K., 2007, ”Teknologi Beton”, Biro Penerbit Teknik Sipil, Universitas Gadjah Mada, Yogyakarta.

Yoder, E. J.andWitczak, M. W., 1975, "Principles of Pavement Design", A WileyInterscience Publication, New York. 